\title{
Ludwig M. Lachmann Against the Cambridge School
}

\author{
Carmelo Ferlito ${ }^{1,2, *}$
}

${ }^{1}$ Faculty of Business, School of Economics, INTI International College Subang, Subang Jaya, Malaysia

${ }^{2}$ Institute for Democracy and Economic Affairs (IDEAS), Kuala Lumpur, Malaysia

\begin{abstract}
While in the early 1930s Keynes and Hayek were the major figures in a heated academic debate about money and capital, in which Keynes also and especially involved the Italian Piero Sraffa, it might seem at first sight that the Austrian economist set aside an organic demolition of the ideas expressed in 1936 by his rival in the General Theory. Hayek himself, in the future, would regret not having devoted an organic work to criticising the new Keynesian theories. However, as demonstrated in Sanz Bas (2011), although it is not possible to find a debate such as the one on the Treatise on Money, Hayek's subsequent works do include timely and reasoned criticisms as regards the main conclusions of the new Cambridge macroeconomics.

But the 'Austrian knight' of a new Vienna-Cambridge debate, in the subsequent decades, was the German economist Ludwig M. Lachmann (1906-1990), a student of Hayek at LSE during the 1930s and later a professor in Johannesburg and New York. Lachmann was one of the protagonists of the Austrian revival after 1974 and the founding leader of the 'hermeneutic stream', opposed by the Rothbardian stream.

Lachmann, defending Keynes's subjectivism and expectation theory, revived the Vienna-Cambridge controversy, criticising not Keynes but his followers, in particular the 'new' Cambridge School, developed by Joan Robinson and Piero Sraffa. Lachmann's life sight was to build a new economics paradigm, centred on the idea of market process, expectations and kaleidic society (Shackle); in order to do so he developed a deep attack toward the new Cambridge macroeconomics mainstream, arising from World War II ashes during the 1950s and 1960s. His polemic toward the 'modern' macroeconomics can be read in all his books and papers, but it is particularly evident in Lachmann (1973, [1986a] 1994).

His preferred targets were Sraffa and Joan Robinson, 'guilty', according to Lachmann, to overcome Keynes's subjectivism and to develop a new Neo-Ricardian approach. The resulting macroeconomics is accused to be excessively formalist, ignoring the microfoundations that are at the very root of human action and choice.

But Lachmann's attack was not only an epistemological one. He intensively tried to demolish all the pillars of the Cambridge macroeconomics: capital as aggregate, long run equilibrium, the absence of innovation and technological change and the conception of rate of profit. His starting point was an economics based on human expectations as the only possible source of human actions. A source, however, never at rest, and continuously influenced by technological change and changing information.
\end{abstract}

Keywords: Lachmann, Hayek, Keynes, Sraffa, Business Cycle, Austrian Economics, Expectations, Cambridge, Ricardo.

\section{INTRODUCTION}

With no doubts, in economics we can think about the 1930s as what Shackle ([1967] 2010) calls the years of high theory ${ }^{1}$. In particular, debates about monetary issues, equilibrium notions and business cycle perspectives set standard ideas for all the future development on the same topics. It would be wrong to consider Keynes's General Theory (1936) as the central moment for such a debate. Rather, the central moment needs to be found at the beginning of the

*Address correspondence to this author at the BT-11-8 Saujana Residency, SS16/1, 47500 Subang Jaya, Malaysia; Tel: +60-19-2394148;

E-mail: carmelo@uow.edu.au

${ }^{1}$ Lachmann ([1986a] 1994:141) wrote: «When the history of economic thought in the twentieth century comes to be written, there is no doubt that the decade of the 1930s will occupy a very special place in it. The 'Keynesian revolution', the rise of new theories of competition such as those of Chamberlin and Joan Robinson, the beginnings of growth theory in Harrod's work, all belong to this decade. Prominent thinkers of the century, such as Hicks and Shackle, published their first writings during it. The 1930s were indeed 'years of high theory'». decade, with two central facts happening in England: the publication of Keynes ([1930] 1971) and the arrival in London of Hayek, called by Lionel Robbins in 1931, with the collection of his lectures on business cycle in Hayek ([1931a] 1967). For Austrian economics, «however, this was a tragic decade» (Lachmann [1986a] 1994:141): because of political reasons, many Austrian economists had to leave the country, so Vienna lost the importance she had at the beginning of the century ${ }^{2}$; England arose as the new centre of the economic debate and, while at the beginning of the decade, Hayek entered LSE in a triumphal way, after the Keynesian revolution his importance was drastically reduced $^{3}$.

The 'fight of the century' between Hayek and Keynes began not with their opposite views on

\footnotetext{
${ }^{2}$ On the role of Vienna for economics at the beginning of the $X X$ century see McCaffrey (2012:127) and McCaffrey (2013:27-28).

${ }^{3}$ Lachmann ([1986a] 1994:141).
} 
economic fluctuations and policy remedies, but with the debate on money triggered by Hayek's review of Keynes's Treatise ${ }^{4}$. It was the beginning of the LondonCambridge controversy ${ }^{5}$, which is not yet ended. As the debate following the 2007 economic crisis demonstrates, followers of the two great economists are still fighting following the masters footsteps.

However, the London-Cambridge debate cannot be reduced to the confrontation between Keynes and Hayek. In fact, before the great impact generated by the General Theory, the Italian economist Piero Sraffa launched a radical criticism to Prices and Production ${ }^{6}$. Sraffa's criticism is important for several reasons and its impact on the Austrian reflection was probably more radical than the debate with Keynes. Hayek not only spent a lot of energies in replying to Sraffa, but in a way he recognized the validity of certain objections ${ }^{7}$ and faced them in the revision of Prices and Production and in his following works on business cycle ${ }^{8}$, which present strong differences with Hayek ([1931a] 1967).

However, the importance of the Sraffa-Hayek debate goes beyond the debate itself. In fact, it sets a different battleground for Austrian economics. Piero Sraffa was not a Keynesian; rather, he was the protagonist, in Cambridge, of a neo-Ricardian revolution ${ }^{9}$, which had enormous consequences on the evolution of modern economic thought. In the Thirties, Hayek seemed not aware of the implications of such Ricardian perspective 'hidden' into Sraffa's criticism. Inside the Austrian School it was Ludwig Lachmann who recognized the consequences of the Ricardian turning point ${ }^{10}$ and, starting from Hayek's counter-critic, developed a radical opposition toward Sraffian approach. Moreover, Lachmann was able 'to save' some Keynesian insights (subjectivism and expectations ${ }^{11}$ ) to build his Austrian attack to the neo-Ricardian tower.

In section II we will briefly summarize the HayekSraffa debate, giving account of how Lachmann judged

\footnotetext{
${ }^{4}$ Hayek (1931b).

${ }^{5}$ Keynes (1931) is the reply to Hayek (1931b) and the counter Hayekian replica is Hayek (1931c, 1932a).

${ }^{6}$ Sraffa (1932a). The rest of the debate has to be found in Hayek (1932b) and Sraffa (1932b).

${ }^{7}$ See Zappia (1999).

${ }^{8}$ In particular the English translation of Hayek ([1929] 1966), published in 1933; the second edition of Hayek ([1931a] 1967), published in 1935; Hayek ([1933] 1975), which we consider the central work for Hayek's business cycle perspective (see Ferlito 2013:chapter 2 and Ferlito 2014); Hayek ([1939] 1975) and Hayek ([1941] 1952).

${ }^{9}$ See Roncaglia (1990) and Porta (1990).

${ }^{10}$ See in particular Lachmann (1973, 1976d, [1986a] 1994).

${ }^{11}$ But Lachmann ([1943] 1977:65) clarified that the big Keynes's mistake was to consider expectations as 'data'. On the general relationship between Keynes and the Austrian, from a Lachmannian perspective, see Lachmann ([1983] 1994).
}

and further developed such a debate. In section III we will analyse the more general Lachmannian critics to the Cambridge school.

\section{THE HAYEK-SRAFFA DEBATE AND LACHMANN'S CLARIFICATIONS}

Ludwig M. Lachmann (1906-1990) was a German economist who studied with Hayek at the London School of Economics during the $1930 \mathrm{~s}^{12}$. A professor in economics in South Africa, he became, with Israel Kirzner and Murray N. Rothbard, one of the protagonist of the Austrian revival during the period $1974-1976^{13}$. It is important to remember his strong accent on the importance of expectations and the impossibility for the economic system to reach an equilibrium position, even if equilibrating forces are always at work. He gave birth to the 'radical subjectivist' ${ }^{14}$ stream of the Austrian school, characterized by the shift from preferences to expectations and by the introduction of hermeneutics in economics ${ }^{15}$. Even if he found followers such as Don Lavoie $^{16}$ and Mario J. Rizzo ${ }^{17}$, Lachmann attracted the strong attack from Rothbard ${ }^{18}$, which was mitigated by the so called Kirznerian middle ground ${ }^{19}$.

Lachmann probably was the economist that attributed the highest significance to Sraffa's review of Prices and Production. Lachmann ([1986a] 1994:143) considered such a review the first step in the edification of the neo-Ricardian revolution, a prelude to Sraffa (1960). And, in fact, it has to be noted that Sraffa (1932a, 1932b) were the only writings for the Italian economist between his famous The Laws of Returns under Competitive Conditions (1926) and his introduction to the Ricardo's writings collection published in 1951. As we shall see, Lachmann clearly grasped that the most radical aspects of Sraffa's criticism was its attack to the subjectivist perspective. Under this point, even the opposition between Keynes and Hayek can be seen as less radical. The hidden part of the attack was, thus, the most important one, because it tried to wake up a value theory which seemed to be abandoned and that nobody was putting under fire. Keynes, in fact, as a follower of Marshall,

\footnotetext{
${ }^{12}$ For a biographical sketch see Mittermaier (1992) and Moss (2000).

${ }^{13}$ See Blundell (2014) and Vaughn (1994:92-111).

${ }^{14}$ See Koppl and Mongiovi (1998).

${ }^{15}$ Lachmann (1990).

${ }^{16}$ Lavoie (1990)

${ }^{17}$ O'Driscoll and Rizzo ([1985] 2002) and Rizzo (1979).

${ }^{18}$ See Rothbard ([1989] 2011, [1992] 2002). For the debate LachmannRothbard on hermeneutics and disequilibrium see also Rizzo ([1992] 2002), Boettke, Horwitz and Prychitko ([1986] 2002), Selgin ([1988] 1990) and Antiseri (2011).

${ }^{19}$ Kirzner $(1992: 3-54 ; 2000: 132-148)$
} 
remained a subjectivist. Sraffa, instead, while criticising money and capital theory aspects, was attempting to resurrect the labour value theory. But, as Lachmann ([1986a] 1994:144) pointed out, Sraffa «never informed his readers that the presuppositions of the views he presented to them, since they reflected an analytical creed which had fallen into oblivion sixty year earlier and was therefore bound to be unfamiliar to them, were, the them at least, 'new'». According to Lachmann ([1986a] 1994:144), the Italian economist could not reveal his real intentions, because his readers had not followed him: they were too used to the Marshallian perspective. Only at page 50 of the review we can find Sraffa talking about equilibrium and it is easy to understand that he had in mind the 'classical' perspective according to which in the long run price equals cost of production ${ }^{20}$. Such a perspective is radically different with what Hayek had in mind during that years, a neoclassical equilibrium linked with balance between supply and demand ${ }^{21}$.

It is time to take a look to the Sraffa-Hayek debate and the note that Lachmann drew on it, focusing on the following points: 1 . The role of money, 2 . The relation between saving and investment, 3 . Malinvestment and forced saving, 4. The distinction between natural and monetary rate of interest, 5 . The role of expectations.

\section{II.1. The Role of Money in the Economic System}

The first argument is related with the role of money in the economic system. According to Sraffa (1932a:43-44), Hayek failed to identify the differences between a monetary economy and a non-monetary one, in particular attributing to money the simple function of medium of exchange. For Sraffa, such a position was not consistent with the desire to bring out monetary policy prescriptions. And, moreover, such accusation tried to find out a contradiction with Hayek's wish to base his business cycle theory on the effects on real economy generated by monetary expansion ${ }^{22}$.

Hayek seemed quite annoyed by this objection and attributes it to a misunderstanding in Sraffa's view ${ }^{23}$.

On this point, Lachmann did not extend Hayek's defence and limited himself in arguing that Sraffa failed

\footnotetext{
${ }^{20}$ Sraffa (1932a:50): «But if, for any reason, the supply and the demand for a commodity are not in equilibrium (i.e. its market price exceeds of fall short of its cost of production), its spot and forward prices diverge».

${ }^{21}$ On the initial Hayekian perspective on equilibrium see in particular Hayek ([1928] 1994). On the evolution of the Austrian perspective on equilibrium see Tieben (2012:chapters 9 and 11).

${ }^{22}$ Zappia (1999:4).

${ }^{23}$ Zappia (1999:6)
}

to recognize the relevance of Austrian capital theory; and this is surprising for a Ricardian ${ }^{24}$.

\section{II.2. Saving and Investment}

The second important point analysed by Lachmann ([1986a] 1994:147-148) was the relationship between saving and investment.

We have to remember that we are in 1932, half-way between Treatise and General Theory, and before the Myrdalian distinction between magnitudes ex ante and ex post became known outside Sweden. Keynesians, using the terminology of the Treatise, spoke of the divergence between savings and investment (meaning ex ante) caused by the fact that in our society savers and investment decision-makers are typically different classes of people. Austrians like Mises and Hayek, by contrast, subscribed to the view, which at that time was a tenet of all mainstream economics, and nothing particularly Austrian, that saving determines investment through the interest mechanism (Lachmann [1986a] 1994:147-148).

This was a central point, because, as it is well known, an artificially induced disproportion between saving and investment, generating malinvestment and impeding the interest rate mechanism to work, is the cause of economic fluctuations according to the Austrians. As Lachmann ([1986a] 1994:148) pointed out, it was impossible for Sraffa to catch the essence of Hayek's position: in fact, in Ricardo's world, people were rigidly divided into social classes and the possibility of saving to affect investment was simply absurd.

But Lachmann's perspective on this point was similarly astonishing. In fact, he moved away from the Austrian perspective according to which savings determine investment, but at the same time he was not embracing Keynesian perspective according to which investment determines savings.

Today there appears to be fairly wide agreement that, in modern industrial

\footnotetext{
${ }^{24}$ Lachmann ([1986a] 1994:146-147).
} 
society at least, we had better refrain from saying either that savings determine investment of that investment determines savings. In the first place, there is no such thing as a rate of interest, there is a structure of interest rates on a wide variety of financial assets in a complex network of asset markets linked by intermediation. The elements of this structure respond to a large variety of influences prompted in part by divergent expectations about the magnitudes of rates of interest in the future. Put briefly, it is impossible to say that the rate of interest brings savings and investment into equality as such a statement would imply that its function is confined to the market for new capital, while in reality it extends to the markets for all existing assets on each of which the rate of yield has to equate supply and demand. On the other hand, as Hicks showed in The Crisis in Keynesian Economics (Hicks 1974:9-30), the Keynesian teaching that investment determines savings via the multiplier process is also untenable, at least without considerable qualification (Lachmann [1986a] 1994:148-149).

Such a view about interest rate was quite in conflict with the traditional Austrian perspective. We shall come back on Lachmann's interest rate view later.

\section{II.3. Malinvestment}

Next point is related with what the Austrian tradition calls malinvestment, investment brought out by entrepreneurs when the intertemporal structure of preferences is not in equilibrium. According to Hayek, "capital resources brought into existence in response to a money rate of interest below the level of the natural rate cannot be maintained once credit inflation has been stopped and monetary equilibrium is restored. Their owners and their creditors suffer capital loss» (Lachmann [1986a] 1994: 149).

Sraffa could not accept such a perspective and again tried to set the analysis on a class conflict basis. $\mathrm{He}$ simply affirmed that what happens with malinvestment and forced saving is a robbery operated by one of the classes. What Sraffa seemed not able to understand, as Hayek (1932b:243-244) stressed, was that, after a period of malinvestment, capital goods can even retain their physical form, but they can still suffer a reduction of value, due to the fact that their utilization was mis-directed ${ }^{25}$. For Sraffa, capital destruction as conceived by Austrian tradition was not admissible.

Lachmann devoted his main book to capital theory ${ }^{26}$ so he felt comfortable in attacking Sraffa on this point. The 'original sin' of Neo-Ricardian capital theory was to focus on a vision of capital as something abstract and homogeneous. As developed in Lachmann ([1956] $1978)^{27}$, capital can be considered only as «concrete and heterogeneous» (Lachmann [1986a] 1994:150). Every attempt to consider capital as an aggregate and unlinked with expectations is, for Lachmann, terribly wrong. Also on this point, the German economist was the most radical one among the Austrians and even highly critical with Böhm-Bawerk ${ }^{28}$, the founder of the so called Austrian capital theory ${ }^{29}$.

According to Lachmann ([1986a] 1994:150), in a certain moment, only certain forms of capital combinations can produce productive results. Therefore, it can be deduced that capital is not the element originating the production process, in the way that work and natural resources may be ${ }^{30}$. This denotes an entirely human characteristic - the value that man adds to what already exists. Only mankind is able to imagine and consequently create something completely new starting from existing but independent elements. Only man can imagine turning a stick and a stone into a spear. This creative nature embodies the entrepreneurial essence of human action. The creation of capital goods therefore is a specific feature of human creativity. It is what, in economic terms, is usually called investment: the use of certain inputs, or resources, within a production process in order to generate output ${ }^{31}$.

The revolutionary element introduced by Lachmann in Austrian theory of capital lies in not referring to it as a macro-economic aggregate. Austrians, rather, in resuming the Mengerian tradition, prefer a reference to various capital goods by acknowledging the heterogeneous nature ${ }^{32}$ of a magnitude that cannot be

\footnotetext{
${ }^{25}$ Lachmann ([1986a] 1994:150).

${ }^{26}$ Lachmann ([1956] 1978).

${ }^{27}$ And clearly summarized in Lachmann (1976f).

${ }^{28}$ Menger considered Böhm-Bawerk's theory of capital as one of the biggest mistakes ever made (Lachmann [1976a] 1977:27), while Lachmann (1976f:145) judged it inadequate for inclusion in the Austrian paradigm.

${ }^{29}$ Ferlito (2013:31-32). According to Lachmann ([1976a] 1977:27), «BöhmBawerk was, at least in his theory of capital and interest, a Ricardian».

${ }^{30}$ Böhm-Bawerk ([1910] 1998:99).

${ }^{31}$ Hayek ([1941] 1952:66).

${ }^{32}$ Lachmann ([1956] 1978:2): «capital resources are heterogeneous». See also Horwitz (2000:47).
} 
constituted as an aggregate and in which the time factor, in a real sense, plays a key role.

These are elements that Sraffanian perspective, being Neo-Ricardian, could not accept. And at the same time, according to Lachmann, Sraffa was not able to understand the importance of expectations for a new capital theory. In fact, as explained in Lachmann (1947, p. 204), the form that the structure of capital takes is defined by none other than production plans (determined by expectations), which use different combinations of production factors. The relative extents to which these factors become part of the combinations (production coefficients) identify the extent to which these factors are complementary to each other.

It might be said that the Lachmann, given the nonhomogeneity of capital as an essential fact of economic reality, developed a structural conception of capital, in contrast to the aggregating vision of Neo-Ricardians, neo-classics and Keynesians. According to the German economist, Sraffa missed a great occasion linking himself to the Ricardian vision on capital.

\section{II.4. Natural Rate of Interest}

The point regarding the natural rate is probably the most important one. Austrian position, influenced by Wicksell, is very peculiar on this point and it is important to clarify it before going ahead with the Sraffa-Lachmann debate. Austrian economics uses the distinction, introduced by Wicksell, between two rates, one natural (equilibrium ${ }^{33}$ ) and one monetary. The equivalence between natural rate and monetary rate is one of the three conditions set by Wicksell for the existence of a situation of monetary equilibrium. The second is the existence of equilibrium on the capital market (savings are equal to investments). The third is the presence of equilibrium on the consumer goods market, i.e. stability in price levels ${ }^{34}$.

In order to set the notion of natural interest rate, it is important to point out the law of time preference, according to which «other things being equal, humans always place present goods higher than future goods on their scales of value» (Huerta de Soto [2000]

\footnotetext{
${ }^{33}$ Hayek ([1929] 1966:139n) wrote: «The term 'equilibrium rate of interest' which, I believe, was introduced into Germany in this connection, by K. Schlesinger in his Theorie der Geld-und Kreditwirtschaft (München and Leipzig, 1914, p. 128) seems to me preferable in this case to the usual expression of 'natural rate' or 'real rate.' Alfred Marshall used the term 'equilibrium level' as early as 1887 (cf. Official Papers of Alfred Marshall, $p$. 130)».

${ }^{34}$ See Zähringer (2012:305-306)
}

2010:50); on this assumption, we can define «the interest rate [as] the market price of present goods in terms of future goods» (Huerta de Soto [2000] 2010:51). It is therefore limiting and profoundly wrong to define the interest rate as the cost of money. The capital market is only a particular market for goods, where the action of the interest rate is the most evident but not the only one. In this particular market, the offer - sellers - is represented by consumers, those who have present goods and are willing to forego them to some extent, defined precisely by the interest rate ${ }^{35}$. One of the forms in which such foregoing takes place is savings; consumers forego present money as a function of future money; they therefore offer money to the market. Who represents demand? Entrepreneurs who need money today in order to implement their industrial projects. Therefore, for the capital market, the natural interest rate is that particular rate which allows the offer (consumer savings) to meet demand (entrepreneur investments).

Yet the law of time preference does not apply only to the capital market. It should be extended to the entire economic system, where the natural rate is consequently that rate of equilibrium which reflects the temporal preferences of economic agents. Obviously, this is a theoretical level but one to strive for. The monetary rate, on the other hand, in contemporary economic systems is set imperiously by monetary authorities.

Hayek ([1933] 1975:145) said that «an equilibrium rate of interest would then be one which assured correspondence between the intentions of the consumers and the intentions of the entrepreneurs. And with a constant rate of saving this would be the rate of interest arrived at on a market where the supply of money, capital was of exactly the same amount as current savings».

The capital market, so highly emphasised by the dominant theory when discussing interest rates, is therefore only one among many markets. On the other hand, according to Austrian economists, it is possible to define an interest rate for the economic system, which measures the more general structure of time preferences. As regards consumers, it defines the relationship between consumption and saving. In the case of entrepreneurs linked to investments, it measures the propensity towards the future, that desire

\footnotetext{
${ }^{35}$ Huerta de Soto ([2000] 2010:51-52).
} 
to undertake long-term projects in the investment goods sector that makes the production structure more circular and the production period longer, compared to investments in consumer goods and investments having a faster realisation cycle.

In this scenario, the natural rate measures the equilibrium between general time preferences; in a future-oriented system, consumers are more savingsoriented, thereby encouraging the accumulation of loanable funds that can be used by entrepreneurs in long-term projects. A present-oriented society, in contrast, has a greater propensity towards consumption on the consumer side, while investors do not lengthen the production process.

The level of equilibrium for a combination of time preferences is measured by the natural interest rate, which in turn corresponds to a well-defined structure of the production process. The key element that, by fuelling a modification of the intertemporal structure of production, generates a cycle of expansion and crisis is given by a change in level of the natural rate.

When publishing Prices and Production, Hayek was at the beginning of the analysis of the possibility of the difference between natural and monetary rate, induced by banks action and bringing out economic crisis. Sraffa's criticism on this point was very crucial, denying the existence of such a natural rate of interest.

If money did not exist, and loans were made in terms of all sorts of commodities, there would be a single rate which satisfies the conditions of equilibrium, but there might be at any one moment as many natural rates of interest as there are commodities, though they would not be equilibrium rates. The arbitrary action of the banks is by no means a necessary condition for the divergence; if loans were made in wheat and farmers (or for that matter the weather) 'arbitrarily changes' the quantity of wheat produced, the actual rate of interest on loans in terms of wheat would diverge from the rate on other commodities and there would be no single equilibrium rate (Sraffa 1932a: 49).

And later on Sraffa argued that on any forward market the ratio between forward and spot price implies a rate of interest. Here we have the passage in which Sraffa clearly stated what he meant by equilibrium: «It will be noticed that, under free competition, this divergence of rates is as essential to the effecting of the transition as is the divergence of prices from the costs of production; it is, in fact, another aspect of the same thing» (Sraffa 1932a:50).

Thus, while, following Mises, Hayek argued that an unsustainable boom is caused when the banks charge a monetary rate of interest lower than the natural one, Sraffa denied the existence of such a thing like a natural rate of interest outside of the steady-state equilibrium $^{36}$.

Lachmann raised four objections on this topic. First of hall, Lachmann ([1986a] 1994:152) stressed again that Sraffa had in mind a classical view on equilibrium, centred on the long-run relationship between price and cost of production.

\section{Secondly,}

this complex of relationships is given expression in a context of spot and forward markets. Forward prices, while evidently determined by expectations, are always nearer to equilibrium prices than are spot prices, though it is not suggested that they ever coincide. As forward markets without expectations are hardly conceivable, expectations are introduced, albeit in somewhat attenuated form: they are always orientated to equilibrium price (Lachmann [1986a] 1994:152-153).

Thirdly, Lachmann ([1986a] 1994:153) clarified that in the classical view changes in demand acts immediately on market prices, but in the long run their effect is visible on quantities and not on equilibrium prices. Fourthly, in Sraffa's critics there was no room for discussion of the relationships between markets for different commodities, while attention was paid only on the relations between market and equilibrium prices.

However, the main critics that Sraffa launched against Hayek was that the discrepancy between monetary and natural rate is characteristics of a money economy. And that, if transactions would be done in commodities, we should have more than one natural interest rate.

An essential confusion [...] is the belief that the divergence of rates is a

\footnotetext{
${ }^{36}$ Murphy (n.d.:3).
} 
characteristic of a money economy: and the confusion is implied in the very terminology adopted, which identifies the "actual" with the "money" rate, and the "equilibrium" with the "natural rate". If money did not exist, and loans were made in terms of all sorts of commodities, there would be a single rate which satisfies the conditions of equilibrium, but there might be at any one moment as many "natural" rates as there are commodities, though they would not be "equilibrium" rates (Sraffa 1932a:49).

Sraffa (1932a:51), analysing Hayek's policy implications, added:

[l]n times of expansion of production, due to additions to savings, there is no such thing as an equilibrium (or unique natural) rate of interest, so that the money rate can neither be equal to, nor lower than it [...]. [T]here is a "natural" rate of interest which, if adopted as bank-rate, will stabilise a price-level (i.e. the price of a composite commodity): it is an average of the "natural" rates of the commodities entering into the price-level, weighted in the same way as they are in the price-level itself. What can be objected to is that such a price-level is not unique, and for any composite commodity arbitrarily selected there is a corresponding rate that will equalise the purchasing power, in terms of that composite commodity, of the money saved and of the additional money borrowed for investment.

In his reply, Hayek admitted the possibility that there is not a single equilibrium rate, creating a certain confusion on the matter. But, instead, Hayek clarification helped in moving the debate forward.

Mr. Sraffa denies that the possibility of a divergence between the equilibrium rate of interest and the actual rate of interest is a peculiar characteristic of a money economy. And he thinks that "if money did not exist, and loans were made in terms of all sorts of commodities, there would be a single rate which satisfies the conditions of equilibrium, but there might, at any moment, be as many 'natural' rates of interest as there are commodities, though they would not be 'equilibrium' rates" ( $p$. 49). I think it would be truer to say that, in this situation, there would be no single rate which, applied to all commodities, would satisfy the conditions of equilibrium rates, but there might, at any moment, be as many "natural" rates of interest as there are commodities, all of which would be equilibrium rates [...]. There can, for example, be very little doubt that the "natural" rate of interest on a loan of strawberries from July to January will even be negative, while for loans of most other commodities over the same period it will be positive (Hayek 1932b:245).

On this point, differences between Hayek and Sraffa emerged mainly because of the different vision about equilibrium. Hayek had in mind an intertemporal situation of equilibrium prices in which actors have no incentive in changing their behaviour. Instead, Sraffa was concerned with the classical long run equilibrium ${ }^{37}$. Thus, as clarified by Murphy (n.d.:8), a steady state economy, in which relative prices remain stable in each period, was considered both by Sraffa and Hayek as an equilibrium situation. Instead, according to Sraffa, there was no possibility of such an equilibrium in a dynamic economy; in Hayek's veiw, on the contrary, dynamic equilibrium is conceivable when economic actors are able to anticipate relevant changes.

However, for Lachmann ([1986a] 1994:54) Hayek's admission about the existence of multiple natural interest rates was a fatal concession to Sraffa. And on this point Lachmann wished to clarify.

It is not difficult, however, to close this particular breach in the Austrian rampart. In a barter economy with free competition commodity arbitrage would tend to establish an overall equilibrium rate of interest. Otherwise, if the wheat rate were the highest and the barley rate the lowest of interest rates, it would become profitable to borrow in barley and lend in wheat. Inter-market arbitrage will tend to establish an overall equilibrium in the loan market such that, in terms of a third commodity serving as numéraire, say

\footnotetext{
${ }^{37}$ Murphy (n.d.:7).
} 
steel, it is no more profitable to lend in wheat than in barley. This does not mean that actual own-rates must all be equal, but that their disparities are exactly offset by disparities between forward prices. The case is exactly parallel to the way in which international arbitrage produces equilibrium in the international money market, where differences in local interest rates are offset by disparities in forward rates. In overall equilibrium it must be as impossible to make gains by 'switching' commodities as currencies (Lachmann [1986a] 1994:154).

This overall equilibrium rate of interest, Lachmann ([1986a] 1994:154) added, should be different with Sraffa's classical long run equilibrium but also with Hayek's view.

It requires a vigilant and efficient arbitrage acting between markets, a special type of entrepreneurial action and institutions appropriate to it. What Hayek should have said is not that there might be as many rates of interest as there are commodities all of which would be equilibrium rates, but that only some of them would be. While overall equilibrium requires equality of demand and supply in each single market, the latter is not a sufficient condition of the former (Lachmann (1986a) 1994:155).

According to Lachmann, therefore, the weakness of a «natural-rate concept is not that it pertains to a barter, rather than a monetary, economy, but that it can be defined uniquely only in the context of full intertemporal equilibrium, which, in Lachmann's view, made it useless as a policy instrument» (Glasner and Zimmerman 2012: 15).

It seems that Hayek partially moved toward Sraffa's position in recognizing that the discrepancy between natural and monetary rate had not to be confined to the money economy ${ }^{38}$.

Traditionally, disproportion between the natural rate and the monetary rate can be generated when the monetary rate is driven by someone below the natural rate. This is the situation that Hayek had in mind with

\footnotetext{
${ }^{38}$ Zappia (1999:19-24).
}

Prices and Production. Therefore, it seems that without banks action such disproportion cannot arise. However, it was Hayek who introduced a second possibility with the revisions of his works: the natural rate rises above the monetary rate. How can this occur? Through positive profit expectations. If entrepreneurs, whose psychological dynamics are fundamental in any economic process, are pervaded by a positive sentiment, i.e. if they are convinced that they can start profitable industrial projects and have excellent profit expectations, they will be encouraged to request more credit in order to begin longer production processes. This means they have changed their time preferences in becoming more future-oriented.

It is an apparently unimportant difference in exposition which leads one to this view that the Monetary Theory can lay claim to an endogenous position. The situation in which the money rate of interest is below the natural rate need not, by any means, originate in a deliberate lowering of the rate of interest by the banks. The same effect can be obviously produced by an improvement in the expectations of profit or by a diminution in the rate of saving, which may drive the 'natural rate' (at which the demand for and the supply of savings are equal) above its previous level; while the banks refrain from raising their rate of interest to a proportionate extent, but continue to lend at the previous rate, and thus enable a greater demand for loans to be satisfied than would be possible by the exclusive use of the available supply of savings (Hayek [1929] 1966:147).

In seeking the reasons for the second case introduced by Hayek, we can even find a link with Schumpeter.

The reasons for this can be of very different kinds. New inventions or discoveries, the opening up of new markets, or even bad harvests, the appearance of entrepreneurs of genius who originate 'new combinations' (Schumpeter), a fall in wage rates due to heavy immigration; and the destruction of great blocks of capital by a natural catastrophe or many others. We have already seen that none of these reasons is in itself sufficient to account for an 
excessive increase of investing activity, which necessarily engenders a subsequent crisis; but that they can lead to this result only through the increase in the means of credit which they inaugurate (Hayek [1929] 1966:148).

With the evolution of Hayek business cycle theory, in particular with Hayek ([1933] 1975), the Hayekian focus switched from the role of monetary manipulation to the role of expectations ${ }^{39}$. The Austrian economist moved toward a concept of equilibrium as intertemporal plans coordination, which is different with what he had in mind with the first edition of Prices and Production. It may be argued, thus, that some of the Sraffa's criticisms were considered by Hayek in his revision ${ }^{40}$. But, it seems, instead, that Lachmann was not able to catch the peculiarities Hayek's evolution.

\section{II.5. Expectations}

The final part of Lachmann's criticism toward Sraffa was devoted to the issue of the expectations, the most beloved topic for the German economist ${ }^{41}$. In fact, Lachmann is the economist who most deeply analysed the concept of expectations, re-interpreting them dynamically and inserting them in the Austrian theoretical paradigm.

Acknowledging Keynes's important function in having introduced the concept of expectations in an organic way with A Treatise on Money ([1930] 1971) ${ }^{42}$, and referring to Shackle's contribution ${ }^{43}$, an Austrian turned partially Keynesian ${ }^{44}$, Lachmann sought to engage his own contribution completely within the Austrian tradition, albeit with the necessary distinctions.

\footnotetext{
${ }^{39}$ On this see in particular Ferlito (2013:paragraph 2.8) and Ferlito (2014).

${ }^{40}$ For a full account on this, see Zappia (1999).

${ }^{41}$ Lachmann ([1976a] 1977:28): "Austrian economics reflects a "subjectivist" view of the world. The subjective nature of human preferences is at its root. But in a world of change the subjectivism of expectations is perhaps even more important than the subjectivism of preferences».

${ }^{42}$ Garrison (1986) labeled Lachmann Austro-Keynesian. As noticed in Boettke and Sullivan (1998), Lachmann was not able to bring his radical subjectivism to its extreme consequences. In fact, while denying the possibility for equilibrating forces to prevail, because of the kaleidic society, at the same time he advocated government intervention in case of crisis, in particular in Lachmann (1935; [1956] 1978). His interventionism is at odd with his radical perspective on subjectivism. However, we have reason to believe that such policy activism, expressed mainly in his M.Sc. dissertation and his first book, was abandoned later on, as it was never mentioned again.

${ }^{43}$ George Lennox Sharman Shackle (1903-1992) was born in Cambridge and was therefore British. Our definition of him as 'Austrian' refers to his scientific approach. He earned his Ph.D. at the London School of Economics in the 1930 s under the guidance of Hayek.

${ }^{44}$ As told by Rothbard, Lachmann was fond of saying: "When I arrived in London in the early 1930s, it was safe to say that everyone at the London School of Economics was an Austrian. After the war, however, Hayek and I were the only Austrians left».
}

In particular, he felt that the Austrians missed the opportunity to insert expectations within their own thinking in an organic way.

It is a curious fact that, when around 1930 (in Keynes's Treatise on Money) expectations made their appearance in the economic thought of the Anglo-Saxon world, the Austrians failed to grasp with both hands this golden opportunity to enlarge the basis of their approach and, by and large, treated the subject rather gingerly (Lachmann 1976e:58).

In truth, Lachmann's criticism may even seem to be too severe ${ }^{45}$. Hayek ([1929] 1966:147) had already recognised the central role of expectations, when he claimed that positive expectations of profit can guide entrepreneurs to change their preferences, becoming more future-oriented, thereby leading to a rise in the equilibrium interest rate. This step is also central to Hayek's fundamental work ([1933] 1975).

However, Lachmann sought to be more radical: he acknowledged that Hayek discussed the issue of expectations; yet, he 'accused' him of not having worked enough on the causes and consequences that a divergence in expectations coul generate ${ }^{46}$. The German economist therefore embraced Shackle's concept of the kaleidic society ${ }^{47}$, «a society in which sooner or later unexpected change is bound to upset existing patterns, a society "interspersing its moments or intervals of order, assurance and beauty with sudden disintegration and a cascade into a new pattern"» (Lachmann 1976e:54). In contrast, for Hayek, the definition of a dynamic balance, based on the coordination of plans, in any case requires a certain closeness to a situation of general economic equilibrium $^{48}$.

Expectations are consequently the hallmark of a society made of real players which, starting precisely from them, form their own plans for the future, meeting and modifying knowledge and the plans themselves. This generates the kaleidoscopic world, a world where change is constant. And this, according to Lachmann (1976e), can be the basis for developing a common ground starting from the similar observations and conclusions reached by Shackle and Mises; precisely

\footnotetext{
${ }^{45}$ See Selgin ([1988] 1990:75).

${ }^{46}$ Lachmann ([1976e] 1977: 58).

${ }^{47}$ See Shackle ([1972] 2009:76-79).

${ }^{48}$ Rizzo ([1992] 2002:184).
} 
because of these observations concerning uncertainty, the inadequacy of mathematical time and probabilistic calculation applied to economic theory, the two authors developed a similar methodology.

In a kaleidoscopic society, moreover,

the equilibrating forces, operating slowly, especially where much of the capital equipment is durable and specific, are always overtaken by unexpected change before they have done their work, and the results of their operation disrupted before they can bear fruit. [...] Equilibrium of the economic system as a whole will thus never be reached (Lachmann 1976e:7071).

According to Lachmann, expectations are not something 'up in the clouds'; without them, there is no economic activity as such; it is starting from expectations that every decision is taken with the intention of making a profit or achieving personal satisfaction. However, these attempts emerge in a context of imperfect knowledge and an unexpected and unpredictable future ${ }^{49}$. And, again, dynamic equilibrium does not lie in the coherence of expectations but rather in the individual process which each agent enacts in the attempt to achieve them.

However, expectations, although they are a fundamental element in Lachmann's analysis, cannot be analysed as if they were aspects of a problem, as Schumpeter also acknowledged ${ }^{50}$. Rather than being explanatory variables, they should perhaps be seen as economically indeterminate elements ${ }^{51}$. However, Lachmann himself, faced by the accusation that in his vision the indeterminacy of expectations may lead to theoretical nihilism, clearly responded that human action "is not determinate, but neither is it arbitrary", and «human action is free within an area bounded by constraints» (Lachmann 1971:37).

It was important to define the role of expectations in Lachmann's view in order to understand the last point of his criticism toward Sraffa ${ }^{52}$. Lachmann ([1986a] 1994:155) stressed how the main difference between Hayek and the Italian economist had to be sought in their different approaches toward equilibrium.

\footnotetext{
${ }^{49}$ See Lachmann ([1982] 2002).

${ }^{50}$ Lachmann ([1943] 1977:66).

${ }^{51}$ Lachmann ([1943] 1977:67).

${ }^{52}$ Lachmann ([1986a] 1994:155-157).
}

For Hayek equilibrium is an ever-present force. Equilibrium prices are primarily governed by demand. The proportions of capital and consumer goods in the gross national product are determined by the relative preferences of saver-consumers. It takes the arbitrary action of the banks to tamper with an otherwise firmly entrenched equilibrium.

For Sraffa real-world market prices are determined by supply and demand. But behind them, as a centre of gravity, there lies the equilibrium position. Equilibrium prices are determined by the objective, partly technical, conditions of production and distribution while demand determines equilibrium quantities of goods produced (Lachmann [1986a] 1994:155).

However, Lachmann ([1986a] 1994:156) recognized to Sraffa the attempt to take in account the great legacy of the subjective revolution. In fact, Neo-Ricardian revolution seemed to neutralize the role of demand, not asking what lies behind it, the motivations of human behaviours (expectations and following plans). Sraffa introduced something that can be called 'market expectations'. Sraffa (1932:50) explained that if there is a shift of demand among commodities, there will be a change in the relative prices: some of them rise, others fall. Supply will also change bringing out a change in the long run equilibrium price. Thus, expectations that are introduced regard only the date on which equilibrium is expected to be restored. What Lachmann ([1986a] 1994:156) stressed is that in a world of uncertainty, no equilibrium position can be actually known.

Therefore, Lachmann pointed out that Sraffa failed to take chance to build his insights inside a subjectivist paradigm.

\section{LUDWIG LACHMANN AGAINST THE CAMBRIDGE SCHOOL}

What we have seen so far is, actually, only part of the general criticism that Lachmann brought out against the Cambridge School and the mainstream economics, including the neoclassical paradigm ${ }^{53}$.

\footnotetext{
${ }^{53}$ Too often the Austrian school is still included into the neo-classical mainstream. For a deep clarification about the big differences between Austrian school and neo-classical paradigm see Huerta de Soto (1998).
} 
Such criticism is developed in particular in Lachmann (1973) but traces of it can be found in many of the German economist's works.

Lachmann was mainly interested in showing how both the Cambridge school and the neoclassical school, even if fighting each other, were not really able to develop economic theories useful for understanding economic processes, in particular economic growth and capital theory in a free market context. The main reason is that both schools, working with macrovariables, ignore the microfoundations behind them, human actions driven by expectations ${ }^{54}$. Instead, the «significance of the Austrian school in the history of ideas perhaps finds its most pregnant expression in the statement that here man as an actor stands at the center of economic events» (Lachmann [1966] 1977:51).

\section{III.1. Macro-Economic Formalism}

The first great problem with the two schools is that they both «conduct their argument within the context of macro-economic equilibrium» (Lachmann 1973:14). They are interested in economy as a whole; thus the origins of the motion of the forces of the economic system are systematically ignored. But, according to Lachmann (1973:15), the real world is a world of disequilibrium, in which equilibrating forces operate but the equilibrating process is never at rest. While it is possible to study equilibrium at micro-level ${ }^{55}$, it becomes hard to analyse equilibrium in the context of the whole economic system, in which the mutual consistency of plans becomes a conditio sine qua non ${ }^{56}$. Lachmann (1973:16) called macro-economic formalism such attitude to work exclusively with macro aggregates ${ }^{57}$, ignoring the microfoundations ${ }^{58}$.

Lachmann (1973:16-17) stated that the Cambridge school was the more at ease with the macro-economic formalism. In fact, they totally repudiated the subjectivist revolution of the 1870 s, originating what Lachmann (1973:17-18) called the 'neo-Ricardian' revolution ${ }^{59}$. The essence of such a revolution needs to

\footnotetext{
${ }^{54}$ Lachmann (1973:11).

${ }^{55}$ See in particular Hülsmann (2000)

${ }^{56}$ Lachmann (1973:15).

${ }^{57}$ Lachmann (1976c:152).

${ }^{58}$ Lachmann (1976d:217)

${ }^{59}$ Lachmann (1973:23-25) mentioned Joan Robinson, Piero Sraffa and Luigi Pasinetti as the main protagonists of such revolution. We need to add, following Roncaglia (1990), Garegnani and Paolo Sylos Labini. The latter, in particular, developed a neo-Ricardian approach mixing his passions for Smith, Schumpeter and Keynes. See, in particular, Sylos Labini ([1956] 1962, 1984, 1993). See also Ferlito (2011).
}

be found in the following lines from Robinson (1956) quoted by Lachmann: «Economic Analysis, serving for two centuries to win an understanding of the Nature and Causes of the Wealth of Nations, has been fobbed off with another bride - a Theory of Value» ${ }^{60}$. For this reason, Lachmann refused to label the Cambridge school as neo-Keynesian.

Keynes, for all his interest in macroeconomics, owed little to Ricardo and all his life remained a subjectivist, who refused to cast the inducement to invest in the mould of a macro-variable such as the acceleration principle (Lachmann 1973:18).

On the contrary, for neo-Ricardians there is no room for a subjectivist analysis. They focused not on the analysis of human action, but human re-action. Dividing individuals in social classes, the Cambridge school was forced to confine real human beings into stereotyped behaviours, so that imaginary «beings take the place of real people» (Lachmann 1973:19). On the other side, the neoclassical school was also unable to rediscover its subjectivist origin, trapped by its obsession with statistical verification. In fact, if any macro-economic argument would be linked with micro-economic foundations, it would become too difficult to trust statistical verification: while statistical data are collected in a disequilibrium world, macroeconomic theory aims to describe general equilibrium situations ${ }^{61}$.

\section{III.2. Rate of Profit}

However, Lachmannian critics was not only a methodological one. He touched several points that he considered not adequate in the Cambridge economics. The first consideration regarded the rate of profit $^{62}$. Ricardo, Marx, neo-Ricardians, Keynes and even Böhm-Bawerk assumed capital to be homogeneous; this allowed them to define univocally a uniform rate of profit, linked with the return on capital ${ }^{63}$. But, Lachmann (1973:26) argued, such assumptions and conclusions cannot be considered valid in a free market economy. First of all, profit needs to be considered simply as the difference between the price at which a commodity is sold and its cost to the seller. With such a definition,

\footnotetext{
${ }^{60}$ The same criticism against the focus of economic analysis and the need for a return to the classical economics is present in Sylos Labini (2004).

${ }^{61}$ Lachmann (1973:21-22).

${ }^{62}$ Lachmann (1973:25-27).

${ }^{63}$ See also Lachmann ([1958] 1977; 1986b:chapter 4).
} 
profit can have also a negative magnitude. Moreover, profits have to be linked with entrepreneurial action in the market economy. Each company or entrepreneur acts in order to maximize profit; however, motivation toward a positive profit and success in achieving the target are different things. The very nature of market economy renders the success of all plans impossible ${ }^{64}$. Equilibrium, as pointed out in Hülsmann (2000), exists only ex ante: plans are consistent with expectations and the limited available content of information. But, ex post, it is possible to discover that the plan was inadequate to reach the target. Malinvestment can actually happen. Therefore, there is «no such thing [...] as a rate of profit, there are only rates of profit which may differ widely» (Lachmann 1973:26). Such conclusion is drawn from the micro-nature of entrepreneurial action, but also from the heterogeneity of capital, which the Cambridge school, as neoRicardian school, could not accept. And Lachmann had not in mind simply physical heterogeneity; even two identical machines can bring out different results if used in different ways or in different conditions of time and space. Profit is not simply related with the physical features of capital, but above all with capital combinations: capital can produce a profit if used in a certain way ${ }^{65}$. This makes impossible to talk about a uniform rate of profit ${ }^{66}$.

Lachmann (1973:27) admitted that the idea of a uniform rate of profit was consistent with the situation that Ricardo had in mind, the free access to all markets.

If rates were different all capital would flow out of the least profitable branches of industry and accumulate in those most profitable, thus bringing about a uniform level of profitability. This is a feature of lung-run equilibrium (Lachmann 1973:27).

But the present world shows different conditions: capital is mostly durable and specific, so that equilibrating forces could operate only slowly. Such a slow operation of the equilibrating forces will make them to be overtaken by the «disequilibrating forces of unexpected change» (Lachmann 1973:27) ${ }^{67}$. Durability and specificity of capital, as its composition in terms of combination, cannot be ignored. Even what Keynes called 'own rate of interest' cannot be assimilated to the

\footnotetext{
${ }^{64}$ Lachmann (1973:26).

${ }^{65}$ Lachmann ([1956] 1978:3-12).

${ }^{66}$ Lachamann (1973:27)

${ }^{67}$ Lachmann might have in mind Schumpeterian innovation processes.
}

Ricardian rate of return. In fact, Keynes's intuition was more related with the Austrian idea of a natural interest rate reflecting the intertemporal structure of preferences; this is a purely subjective concept, which cannot be considered in the objectivist approach of the Cambridge school ${ }^{68}$.

Moreover, another difference mark between Lachmann and the Cambridge school was that for the German economist profit is essentially a disequilibrium phenomenon $^{69}$. Being generated by the difference between selling prices and purchasing costs, profits cannot arise in an equilibrium context. In the struggle for profit, entrepreneurial function will wake up equilibrating forces, but profit will be present as far as such equilibrium does not prevail. As explained by Kirzner (1973:48):

The pure entrepreneur [...] proceeds by his alertness to discover and exploit situation in which he is able to sell for high prices that which he can buy for low prices. Pure entrepreneurial profit is the difference between the two set of prices. It is not yielded by exchanging something the entrepreneur values less for something he values more highly. It comes from discovering sellers and buyers of something for which the latter will pay more than the former demand.

Entrepreneurial function, seeking for profits, moves the market from a disequilibrium status toward equilibrium $^{70}$. The starting point of human action, in fact, is always a state of disequilibrium, characterized by market ignorance. It is through interaction in the market that knowledge can be transmitted and acquired, bringing out plans revisions. Entrepreneurial alertness allows such changes to happen and, therefore, reducing market-ignorance and driving plans toward mutual compatibility, it is an equilibrating force $^{71}$. The market approach, in fact, focuses

on the role of knowledge and discovery in the process of market equilibration. In particular this approach (a) sees

\footnotetext{
${ }^{68}$ Lachmann (1973:28-29).

${ }^{69}$ Lachmann (1973:31)

${ }^{70}$ Kirzner (1973:69-75). See Ferlito (2015)

${ }^{71}$ «For Hayek the equilibrating process is thus one during which market participants acquire better mutual information concerning the plans being made by fellow market participants. For Mises this process is driven by the daring, imaginative, speculative actions of entrepreneurs who see opportunities for pure profit in the conditions of disequilibrium» (Kirzner 2000:13).
} 
equilibration as a systematic process in which market participants acquire more and more accurate and complete mutual knowledge of potential demand and supply attitudes, and (b) sees the driving force behind this systematic process in what will be described below as entrepreneurial discovery (Kirzner 1997:62).

The equilibrating process consists exactly in the acquisition of better mutual information concerning the plans made by the different market actors ${ }^{72}$. It is only in disequilibrium that profit opportunities actually exist and can be discovered by entrepreneurial alertness ${ }^{73}$. In this sense, alertness allows discovery and discovery plays an equilibrating role, reducing marketignorance $^{74}$. However, in opposition to Kirzner, Lachmann stated that such equilibrating forces, in the market economy, cannot prevail and this fact gives meaning to the competition process: profit persists in the market because disequilibrium is always present in some sector of economic system ${ }^{75}$.

Lachmann (1973:32) drew two conclusions from his analysis on the nature of profit.

First, the ever-elusive and fugitive pricecost differences which are the source of all profits can have no place in the long-term equilibrium world to which the two rival schools [Cambridge and neo-classical schools] are both committed. An equilibrium rate of profit is thus a contradiction in terms.

Secondly, profits are pre-eminently a micro-economic phenomenon. Their basis is to be found primarily in the everchanging pattern of price-cost differences in a thousand different markets. Without understanding this micro-foundation of the phenomenon we cannot understand its essence. We certainly should not be able to formulate a general theory of profits

\footnotetext{
${ }^{72}$ «In the market economy the problem of coordination finds solution in the market process and the key role is played by prices» (Kirzner 1963:38).

${ }^{73}$ "For Austrians [...] mutual knowledge is indeed full of gaps at any given time, yet the market process is understood to provide a systemic set of forces, set in motion by entrepreneurial alertness, which tent do reduce the extent of mutual ignorance. Knowledge is not perfect; but neither is ignorance necessarily invincible. Equilibrium is indeed never attained, yet the market does exhibit powerful tendencies toward it» (Kirzner 1992:5).

${ }^{74}$ Kirzner (1997:68)

${ }^{75}$ Lachmann (1973:32).
}

without it. A macro-economic theory of profit can therefore make little sense.

According to Lachmann (1973:33-35), even if neoclassics and neo-Ricardians (Cambridge) present differences in their analysis of the profit rate $^{76}$, both schools miss the opportunity to understand the true nature of profit, lying in the micro forces of market competition process.

\section{III.3. Economic Growth}

Discussions on matters of economic growth have become a favourite pastime of our age. Among newspaper readers and television viewers all over the world, even among some economists, the notion that in this great age of ours it has become possible to sum up in one single figure the result of the economic activity of groups of individuals in countries, regions, or industries, appears to be accepted as a self-evident truth. Such figures are then used as a measure for comparisons over time and, with gusto, between countries. In many circles a low rate of growth of the gross national product has come to be regarded as a symptom of a social malaise (Lachmann 1973:36).

In the above passage, Lachmann anticipated the present day critics toward GDP as a reliable instrument for measuring economic performances in a country and among countries. But the German economist's aim was not only to criticize the GDP growth as a policy target. His attack was mainly devoted toward the concept of steady-state growth and the way in which neo-classical school and Cambridge school faced the growth problem $^{77}$. In fact, according to Lachmann, again, they were facing a dynamic problem with static instruments. Steady-state growth, the concept with which both school were concerned, is an equilibrium concept ${ }^{78}$.

The equilibrating forces under discussion are macro-economic forces. Some of them we must now regard as suspect: the capital-output ratio, for example, since heterogeneous capital cannot be

\footnotetext{
${ }^{76}$ For neo-classics profit rate and interest rate coincide, while for the Cambridge school they have to be kept sharply distinct.

${ }^{77}$ Lachmann (1973:37-38)

${ }^{78}$ Lachmann (1973:39)
} 
measured in disequilibrium, or the rate of profit we discussed at length. Again we find that the micro-economic foundations from which these macro-economic forces must be supposed to spring are largely ignored. The possibility of such an equilibrium is discussed at length. The question of how it would have to be reached, of the pattern of action required for the 'path' that leads towards it, is in general neglected (Lachmann 1973:39).

Again, Lachmann (1973:39) found occasion to come back to the issue of expectations. According to him, in fact, it is not possible to study situations of growth and change without taking in account expectations and plans, determined by individuals ${ }^{79}$. If attention was paid to such elements, it would be impossible to talk about some macro-economic equilibrium. In fact, to have macro equilibrium, according to Walras, it is necessary that each market is in equilibrium; in turn, for fulfilling such condition, individual equilibrium is necessary. But it is even too obvious that an ex post individual equilibrium is not possible for all the market actors. Certain plans do actually fail ${ }^{80}$. Even whenever expectations were in some way considered, like in Robinson (1956), the Cambridge school referred simply to 'mass expectations', with no room for individual expectations and plans ${ }^{81}$.

In synthesis, the growth path that the Cambridge school had in mind was a path in which future follows the past (like for the modern econometricians) ${ }^{82}$. But in the real world, a world of change, future is unknowable and not all the expectations can be fulfilled on the base of past experience. In an uncertain world, therefore, universal success of plans is not possible and to define an equilibrium growth path is a contradiction ${ }^{83}$.

We must conclude that the concept of equilibrium growth is a misconception. It would require a world of convergent expectations all of which are invariably fulfilled and, resting upon them, of individual plans all of which are consistent with one another. Walrasian general equilibrium makes sense only in a

\footnotetext{
${ }^{79}$ And he stressed that Keynes actually took in account such elements, but the neo-Ricardian school in Cambridge did not.

${ }^{80}$ Lachmann (1973:39).

${ }^{81}$ Lachmann (1973:40).

${ }^{82}$ Lachmann (1976d:218)

${ }^{83}$ Lachmann (1973:41).
}

stationary world in which expectations play no part that could be called economically significant, and in which all plans of households and firms, attuned to the same set of existing prices, are consistent (Lachmann 1973:43).

Lachmann (1973:43) added that there is no middle ground between the stationary state and the real world of the market economy. In the latter, equilibrating forces are often overtaken by disequilibrating forces, driven by divergent expectations and limited information ${ }^{84}$.

\section{III.4. Technical Progress}

Among the disequilibrating forces, a central role is played by technical progress ${ }^{85}$. With such remark, for sure Lachmann demonstrated to have absorbed the Schumpeterian lesson about the disequilibrating power of technical innovations. In the macro-formalist approach of the Cambridge school, of course, such a kind of technical progress poses several problems ${ }^{86}$. While equilibrium, in fact, implies perfect knowledge, economic change is characterized by ever-changing information. How to formalise the technical progress process? It is not possible, indeed.

Some members of the neo-Ricardian revolution tried to take in account the technical progress and its fundamental role for economic development. It is the case of the most important followers of Sraffa, the Italian Paolo Sylos Labini, according to who growth without evolution (or innovation) is inadmissible ${ }^{87}$. However, the analysis, even with the influence from Schumpeter, was still developed in a Ricardian framework and with the neoclassical production function. Such stylization is not able to take into account the fact that the decision process about the introduction of innovation cannot be centralised. It is dispersed in the mind of the economic actors. Market process will 'decide' which decision will be successful and which ones will fail ${ }^{88}$.

\footnotetext{
${ }^{84}$ Lachmann (1976b:126).

${ }^{85}$ Lachmann (1973:44)

${ }^{86}$ Lachmann (1973:45)

${ }^{87}$ See Sylos Labini ([1956] 1962:132-133) and Ferlito (2011:103). And in Sylos Labini (1984:81), the theme is reaffirmed: «If we take into account the tendency of diminishing returns from agriculture and mining, we are bound to recognize that, with unchanging methods of production, the rate of increase of the social product in the long run would necessarily tend to zero. This means that in the long run technological progress is not simply the main factor of economic growth: it is the necessary condition». See also Sylos Labini (1981:41) and Sylos Labini (1989:32)

${ }^{88}$ Lachmann (1973:47-48)
} 


\section{CONCLUSIONS}

The analysis developed so far allows us to see that the famous Hayek-Keynes debates was just a small part of a bigger controversy between the Austrian School and the Cambridge School. In particular, the Italian Piero Sraffa engaged with Hayek a radical debate about the role of money and capital and the concept of equilibrium. However, it is only several decades later that Ludwig M. Lachmann, a student of Hayek at LSE during the 1930s, realized the bigger scope of the Sraffian attack: a neo-Ricardian revolution aiming to destroy the subjectivist revolution of the 1870s. In doing so, Sraffa developed, in Cambridge, a school that abandoned some of the positive insights of Keynes, namely subjectivism and the role of expectations. Therefore, Lachmann engaged himself in a struggle to bring out not only all the weakness of the Sraffian attack, but also to radically criticize the Cambridge neo-Ricardian approach. Such critics will be fundamental in building his radical subjectivism, grounded on the Shackle kaleidic world and on the impossibility for equilibrium to actually happen: even if equilibrating tendencies operate, they are overcome by disequilibrating forces such as divergent expectations and technological change.

\section{REFERENCES}

Antiseri, D. 2011. Contro Rothbard. Elogio dell'ermeneutica. Soveria Mannelli: Rubbettino.

Blundell, J. 2014. "IHS and the Rebirth of Austrian Economics: Some Reflections on 1974-1976". The Quarterly Journal of Austrian Economics 17 (1): 92-107.

Boettke, P.J., Horwitz, S. and Prychitko, D.L. 1986. "Beyond Equilibrium Economics: Reflections on the Uniqueness of the Austrian Tradition". Pp. $121-132$ in Modern Austrian Economics. Archaeology of a Revival, Vol. II: The Age of Dispersal. Edited by P.J. Boettke and S. Boehm. London: Pickering \& Chatto, 2002.

Boettke, P.J., and Sullivan, S.T. 1998. "Lachmann's Policy Activism. An Austrian critique of Keynesian proclivities". Pp. 163-182 in Koppl and Mongiovi (1998).

Böhm-Bawerk, E. von. 1910. "Capitale". Pp. 91-106 in Capitale Valore Interesse. By E. von Böhm-Bawerk. Rome: Archivio Guido Izzi, 1998

Ferlito, C. 2011. "Sylos Labini's Unpublished Notes on Schumpeter's Business Cycles". The Quarterly Journal of Austrian Economics 14 (1): 88-129.

Ferlito, C. 2013. Phoenix Economics. From Crisis to Renascence. New York: Nova Publishers.

Ferlito, C. 2014. "The Natural Cycle: Why Economic Fluctuations are Inevitable. A Schumpeterian Extension of the Austrian Business Cycle Theory". Journal of Reviews on Global Economics 3: 200-219. http://dx.doi.org/10.6000/1929-7092.2014.03.16

Ferlito, C. 2015. "Entrepreneurship: State of Grace or Basic Feature of Human Action? Schumpeter's Leadership vs. Kirzner's Alertness". European Journal of Economic and Social Systems, forthcoming.
Garrison, R. 1986. "From Lachmann to Lucas: on institutions, expectations, and equilibrating tendencies". Pp. 87-101 in Subjectivism, Intelligibility, and Economic Understanding: Essays in Honor of Ludwig M. Lachmann on His Eightieth Birthday. Edited by I.M. Kirzner. New York: New York University Press.

Glasner, D., and Zimmerman, P.R. 2012. "The Sraffa-Hayek Debate on the Natural Rate of Interest". SSRN working paper series, available at SSRN: http://ssrn.com/abstract=2221695 http://dx.doi.org/10.2139/ssrn.2221695

Hayek, F.A. von. 1928. "The System of Intertemporal Price Equilibrium and Movements in the "Value of Money". Pp. 160-198 in Classics in Austrian Economics. A Sampling in the History of a Tradition, Vol. III: The Age of Mises and Hayek. Edited by I.M. Kirzner. London: William Pickering, 1994.

Hayek, F.A. von. 1929. Monetary Theory and the Trade Cycle. New York: Kelley, 1966.

Hayek, F.A. von. 1931a. Prices and Production. New York: Kelley, 1967.

Hayek, F.A. von. 1931b. "Reflections on the Pure Theory of Money of Mr. J.M. Keynes". Economica XI (33): 270-295. http://dx.doi.org/10.2307/2548035

Hayek, F.A. von. 1931c. "The Pure Theory of Money: A Rejoinder to Mr. Keynes". Economica XI (34): 398-403. http://dx.doi.org/10.2307/2549193

Hayek, F.A. von. 1932a. "Reflections on the Pure Theory of Money of Mr. J.M. Keynes, Part 2". Economica XII (35): 22-44. http://dx.doi.org/10.2307/2548974

Hayek, F.A. von. 1932b. "Money and Capital: A Reply to Mr. Sraffa". Economic Journal 42: 237-249. http://dx.doi.org/10.2307/2223821

Hayek, F.A. von. 1933. "Price Expectations, Monetary Disturbances and Malinvestments". Pp. 135-156 in Profits, Interest and Investment and Other Essays on the Theory of Industrial Fluctuations. By F.A. von Hayek. Clifton: Augustus M. Kelley, 1975.

Hayek, F.A. von. 1939. "Profits, interest and Investment". Pp. 3-71 in Profits, Interest and Investment and Other Essays on the Theory of Industrial Fluctuations. By F.A. von Hayek. Clifton: Augustus M. Kelley, 1975.

Hayek, F.A. von. 1941. The Pure Theory of Capital. Chicago: The University of Chicago Press, 1952.

Horwitz, S. 2000. Microfoundations and Macroeconomics. An Austrian Perspective. London and New York: Routledge. http://dx.doi.org/10.4324/9780203456309

Huerta de Soto, J. 1998. "The Ongoing Methodenstreit of the Austrian School". Journal des Economistes et des Etudes Humaines 8 (1): 75-113.

Huerta de Soto, J. 2000. The Austrian School. Market Order and Entrepreneurial Creativity. Cheltenham and Northampton: Edward Elgar, 2010.

Hülsmann, J.G. 2000. "A Realist Approach to Equilibrium Analysis". The Quarterly Journal of Austrian Economics 3 (4): 3-51. http://dx.doi.org/10.1007/s12113-000-1025-1

Keynes, J.M. 1930. "A Treatise on Money". In Collected Writings of John Maynard Keynes, Vols: V-VI. London: Royal Economic Society, 1971.

Keynes, J.M. 1931. "The Pure Theory of Money. A reply to dr. Hayek". Economica XI (34): 389-403. http://dx.doi.org/10.2307/2549192

Kirzner, I.M. 1963. Market Theory and the Price System. Princeton: D. van Nostrand.

Kirzner, I.M. 1973. Competition and Entrepreneurship. Chicago: University of Chicago Press.

Kirzner, I.M. 1992. The Meaning of Market Process. Essays in the development of Modern Austrian Economics. London and 
New York: Routledge.

http://dx.doi.org/10.4324/9780203004456

Kirzner, I.M. 1997. "Entrepreneurial Discovery and the Competitive Market Process: An Austrian Approach". Journal of Economic Literature XXXV: 60-85.

Kirzner, I.M. 2000. The Driving Force of the Market. Essays in Austrian Economics. London and New York: Routledge. http://dx.doi.org/10.4324/9780203465974

Koppl, R., and Mongiovi, G., eds. 1998. Subjectivism and Economic Analysis. Essays in memory of Ludwig M. Lachmann. London and New York: Routledge, 2003.

Lachmann, L.M. 1935. Capital Structure and Depression. Unpublished M.Sc. Thesis, London University.

Lachmann, L.M. 1943. "The Role of Expectations in Economics as a Social Science". Pp. 65-80 in Capital, Expectations, and the Market Process. By L.M. Lachmann. Edited by W.E. Grinder. Kansas City: Sheed Andrews And McMeel Inc., 1977.

Lachmann, L.M. 1947. "Complementarity and Substitution in the Theory of Capital". Pp. 197-213 in Capital, Expectations, and the Market Process. By L.M. Lachmann. Edited by W.E. Grinder. Kansas City: Sheed Andrews and McMeel Inc., 1977.

Lachmann, L.M. 1956. Capital and Its Structure. Kansas City: Sheed Andrews and McMeel, 1978.

Lachmann, L.M. 1958. "Mrs. Robinson on the Accumulation of Capital". Pp. 214-234 in Capital, Expectations, and the Market Process. By L.M. Lachmann. Edited by W.E. Grinder. Kansas City: Sheed Andrews and McMeel Inc., 1977.

Lachmann, L.M. 1966. "The Significance of the Austrian School of Economics in the History of Ideas". Pp. 45-64 in Capital, Expectations, and the Market Process. By L.M. Lachmann. Edited by W.E. Grinder. Kansas City: Sheed Andrews and McMeel Inc., 1977.

Lachmann, L.M. 1971. The Legacy of Max Weber. Berkeley: The Glendessery Press.

Lachmann, L.M. 1973. Macro-economic Thinking and the Market Economy. An essay on the neglect of the micro-foundations and its consequences. London: The Institute of Economic Affairs.

Lachmann, L.M. 1976a. "Austrian Economics in the Present Crisis of Economic Thought". Pp. 25-41 in Capital, Expectations, and the Market Process. By L.M. Lachmann. Edited by W.E. Grinder. Kansas City: Sheed Andrews and McMeel Inc., 1977.

Lachmann, L.M. 1976b. "On the Central Concept of Austrian Economics: Market Process". Pp. 126-132 in The Foundations of Modern Austrian Economics. Edited by E.G. Dolan. Kansas City: Sheed \& Ward.

Lachmann, L.M. 1976c. "Toward a Critique of Macroeconomics". Pp. 152-158 in The Foundations of Modern Austrian Economics. Edited by E.G. Dolan. Kansas City: Sheed \& Ward.

Lachmann, L.M. 1976d. "Austrian Economics in the Age of the NeoRicardian Counterrevolution". Pp. 215-223 in The Foundations of Modern Austrian Economics. Edited by E.G. Dolan. Kansas City: Sheed \& Ward.

Lachmann, L.M. 1976e. "From Mises to Shackle: An Essay on Austrian Economics and the Kaleidic Society". Journal of Economic Literature 14 (1): 54-62.

Lachmann, L.M. 1976f. "On Austrian Capital Theory”. Pp. 145-151 in The Foundations of Modern Austrian Economics. Edited by E.G. Dolan. Kansas City: Sheed \& Ward.

Lachmann, L.M. 1982. "Why Expectations Matter". Pp. 251-269 in Modern Austrian Economics. Archaeology of a Revival, Vol. I: A Multi-Directional Revival. Edited by S. Gloria-Palermo. London: Pickering \& Chatto, 2002.

Lachmann, L.M. 1983. "John Maynard Keynes. A view from an Austrian window". Pp. 179-191 in Expectations and the Meaning of Institutions. By L.M. Lachmann. Edited by D.
Lavoie. London and New York: Routledge, 1994.

Lachmann, L.M. 1986a. "Austrian Economics under Fire: The HayekSraffa Duel in Retrospect". Pp. 141-157 in Expectations and the Meaning of Institutions. By L.M. Lachmann. Edited by D. Lavoie. London and New York: Routledge, 1994.

Lachmann, L.M. 1986b. The Market as an Economic Process. New York: Basil Blackwell.

Lachmann, L.M. 1990. "Austrian Economics: A Hermeneutic Approach". Pp. 132-144 in Lavoie (1990).

Lavoie, D., ed. 1990. Economics and Hermeneutics. London and New York: Routledge.

McCaffrey, M. 2012. "The Influence of the Currency-Banking Dispute on Early Viennese Monetary Theory". Pp. 127-165 in Theory of Money and Fiduciary Media: Essays in Celebration of the Centennial. Edited by J.G. Hülsmann. Auburn: Ludwig von Mises Institute.

McCaffrey, M. 2013. "Conflicting Views of the Entrepreneur in Turnof-the-Century Vienna". History of Economics Review 58: 2743.

Mittermaier, K.H.M. 1992. "Ludwig Lachmann (1906-1990), A Biographical Sketch". Pp. 252-269 in Modern Austrian Economics. Archaeology of a Revival, Vol. I: A MultiDirectional Revival. Edited by S. Gloria-Palermo. London: Pickering \& Chatto, 2002.

Moss, L.S., ed. 2000. "Ludwig M. Lachmann (1906-1990): Scholar, Teacher, and Austrian School Critic of Late Classical Formalism in Economics", American Journal of Economics and Sociology 59 (3): 367-417. http://dx.doi.org/10.1111/1536-7150.00034

Murphy, R. n.d. "Multiple Interest Rates and Austrian Business Cycle Theory". Unpublished paper.

O'Driscoll, G.P., and Rizzo, M.J. 1985. The Economics of Time and Ignorance. London and New York: Routledge, 2002.

Porta, P.L. 1990. "David Ricardo: la sistemazione teorica della concorrenza e del mercato". Pp. 101-147 in II pensiero economico moderno. Edited by G. Becattini. Turin: Utet.

Rizzo, M.J. 1979. "Disequilibrium and All That: An Introductory Essay". Pp. 1-18 in Time, Uncertainty, and Disequilibrium. Edited by M.J. Rizzo. Lexington: D.C. Heath and Company.

Rizzo, M.J. 1992. "Equilibrium Visions". Pp. 175-190 in Modern Austrian Economics. Archaeology of a Revival, Vol. II: The Age of Dispersal. Edited by P. Boettke and S. Boehm. London: Pickering \& Chatto, 2002.

Robinson, J. 1956. The Accumulation of Capital. London: Macmillan.

Roncaglia, A. 1990. "Le scuole sraffiane". Pp. 233-274 in I/ pensiero economico moderno. Edited by G. Becattini. Turin: Utet.

Rothbard, M.N. 1989. "The Hermeneutical Invasion of Philosophy and Economics". Pp. 119-136 in Economic Controversies. By M.N. Rothbard. Auburn: Ludwig von Mises Institute, 2011.

Rothbard, M.N. 1992. "The Present State of Austrian Economics". Pp. 1-59 in Modern Austrian Economics. Archaeology of a Revival, Vol. II: The Age of Dispersal. Edited by P. Boettke and S. Boehm. London, Pickering \& Chatto, 2002.

Sanz Bas, D. 2011. "Hayek's Critique of The General Theory: A New View of the Debate between Hayek and Keynes". The Quarterly Journal of Austrian Economics 14 (3): 288-310.

Selgin, G.A. 1988. Praxeology and Understanding: An Analysis of the Controversy in Austrian Economics. Auburn: Ludwig von Mises Institute, 1990.

Shackle, G.L.S. 1967. The Years of High Theory. Invention \& Tradition in Economic Thought 1926-1939. Cambridge: Cambridge University Press, 2010.

Shackle, G.L.S. 1972. Epistemics and Economics: A critique of economic doctrines. New Brunswick and London: Transaction Publishers, 2009.

Sraffa, P. 1932a. "Dr. Hayek on Money and Capital". Economic Journal 42: 42-53. 
http://dx.doi.org/10.2307/2223735

Sraffa, P. 1932b. "A Rejoinder". Economic Journal 42: 249-251. http://dx.doi.org/10.2307/2223822

Sraffa, P. 1960. Production of Commodities by Means of Commodities. Prelude to a Critique of Economic Theory. Cambridge: Cambridge University Press.

Sylos Labini, P. 1956. Oligopoly and Technical Progress. Cambridge: Harvard University Press, 1962.

Sylos Labini, P. 1981. "I Mutamenti Tecnologici nelle Condizioni Odierne: Riflessioni di un Economista". Moneta e Credito 34 (133): 41-62.

Sylos Labini, P. 1984. The Forces of Economic Growth and Decline. Cambridge and London: MIT Press.

Sylos Labini, P. 1989. Nuove Tecnologie e Disoccupazione. Rome and Bari: Laterza.
Sylos Labini, P. 1993. Progresso Tecnico e Sviluppo Ciclico. Rome and Bari: Laterza.

Sylos Labini, P. 2004. Torniamo ai classici. Produttività del lavoro, progresso tecnico e sviluppo economico. Rome and Bari: Laterza.

Tieben, L.A.W. 2012. The Concept of Equilibrium in Different Economic Traditions. A Historical Investigation. Cheltenham: Edward Elgar. http://dx.doi.org/10.4337/9781781953518

Vaughn, K. 1994. Austrian economics in America. The migration of a tradition. Cambridge: Cambridge University Press. http://dx.doi.org/10.1017/CBO9780511572142

Zappia, C. 1999. "L'influenza di Sraffa sull'evoluzione della teoria di Hayek". Quaderni del Dipartimento di Economia Politica dell'Università degli Studi di Siena, n. 241.

Received on 08-09-2015

Accepted on 08-09-2015

Published on 14-12-2015

DOI: http://dx.doi.org/10.6000/1929-7092.2015.04.25

(C) 2015 Carmelo Ferlito; Licensee Lifescience Global.

This is an open access article licensed under the terms of the Creative Commons Attribution Non-Commercial License (http://creativecommons.org/licenses/by-nc/3.0/) which permits unrestricted, non-commercial use, distribution and reproduction in any medium, provided the work is properly cited. 